\title{
Application of Ozone as an Adjunct Method to Traditional Cavity Preparation in Treating Dental Caries
}

\author{
Dr: Luis Cuesta ${ }^{1}$ and Dr. Manju Natarajan ${ }^{2 *}$ \\ ${ }^{1}$ Switzerland
}

${ }^{2}$ Merrimack College, USA

Submission: January 21, 2019; Published: March 01, 2019

*Corresponding author: Dr. Manju Natarajan, Master of Science in Health Science, Merrimack College, Massachusetts, USA

Abstract

The aim of this case report is to show the effectiveness of gaseous ozone as a cavity disinfectant in treating dental caries. A 41 year old male had caries and it was diagnosed as MOD on tooth \#24 FDA (\#12 ADA). While removing the caries, its extension was deep exposing the pulp a little bit. After the hemorrhage stopped calcium hydroxide was placed on the exposed spot. To disinfect the dentinal cavity floor, a non-traditional but well documented disinfectant called gaseous ozone was used carefully before filling the cavity with composite resin. After 23 months of follow-up there were no post-operative complications noticed proving the efficacy of this method on this case.

Keywords: Caries gaseous ozone; Cavity disinfectant; Ozone in restorative dentistry

\section{Introduction}

Dental caries is one of the two most prevalent and common dental problems among patients [1]. In the US, $91 \%$ of adults aged 20-64 had dental caries of which $27 \%$ had untreated tooth decay [2] and in the Europe, greater than $92 \%$ of adults experienced extensive caries [3]. The statistics is expected to be equal or worse in other parts of the world. The consequences of untreated caries such as periapical lesions, it is acting a source of systemic infection, risk of cellulitis etc. and the need to treat caries is widely comprehended among professional communities. As a result of research and development to address caries treatment effectively, many restorative materials and methods have been found and used successfully over the past decades. The objective of this manuscript is to discuss how a caries lesion was effectively treated through traditional methods with the use of an add-on modern technology called ozone. Ozone is an allotropic form of oxygen and it has been effectively used in various fields of dentistry due to its strong characteristic of the highest oxidation potential [4]. Ozone therapy was first used by a Swiss dentist named Dr. Fish in 1936 [4] and since then it has evolved to becoming a wellestablished complementary treatment method to treat caries in most of the European countries [5]. There are three modes of ozone administration namely, ozonated water, ozonated olive oil and oxygen/ozone gas [6]. Some of the beneficial effects of ozone are as follows [6]:
a) Antimicrobial (bactericidal, virucidal and fungicidal).
b) Immuno-stimulating.
c) Analgesic.
d) Anti-hypoxic and detoxicating.
e) Bio-energizing and bio-synthesizing.

\section{Case Report}

A 41-year-old male patient came for a general check-up. A complete examination was done both intra-orally and extraorally. Extra-oral examination revealed no facial asymmetry and no lymph node swellings. Intra-orally, the patient exhibited a few missing teeth and caries on the upper first premolar which was asymptomatic. The patient's medical history showed nothing concerning and the crop of the panoramic X-ray revealed a midsize dentine cavity on the upper first premolar. Further pathology exists on posterior teeth as well, but it is not relevant for this clinical article on ozone therapy. Upon evaluating the caries both radiographically and clinically it was diagnosed as MOD on tooth \#24 FDA (\#12 ADA) and a decision was made to treat this first. After discussing with the patient, the treatment plan for missing teeth and vertical bone loss was scheduled for following future visits. In order to fill the decayed tooth, below methodical steps were followed: 


\section{Advances in Dentistry \& Oral Health}

a) Teeth isolation - A rubber dam was used to isolate the tooth \#24 (\#12 universal)

b) Upon opening of the tooth cavity, it was found that the caries was larger than expected as compared to assessment based on X-ray and asymptomatic descriptions made by the patient.

c) Then Snoop $®$ caries detector was used to identify the extent of the carious lesion. Caries debridement was carried out through high speed contra-angle handpiece with a diamond bur.

d) Application of caries detector (Snoop $\AA$ ) was repeated and continued after each step of debridement of the carious dentine. While doing so, pulp was exposed minimally, and it did not cause any hemorrhage clotting by itself.

e) Caries debridement was continued until the caries detector showed no dark blue colored spots. In addition, visual and tactile sensation of soft caries dentin were also used as a guide while removing caries lesion.

f) Gaseous ozone at a concentration of up to $5000 \mathrm{ppm}$ was applied for 90 seconds to disinfect the dentinal tubules. The ozone applicator was manufactured by MIO International Ozonytron GmbH, Germany [7]. Next, pulp was covered with Calcium hydroxide $\left(\mathrm{CaOH}_{2}\right)$ followed by enamel etching, application of bonding agent and restored with composite (Tetric Evoflow® as base and Tetric Evo Ceram® in layers).

g) Finally, the occlusal surface was characterized using Enamel Plus HFO® Stain Brown 2 (Figures 1-11).

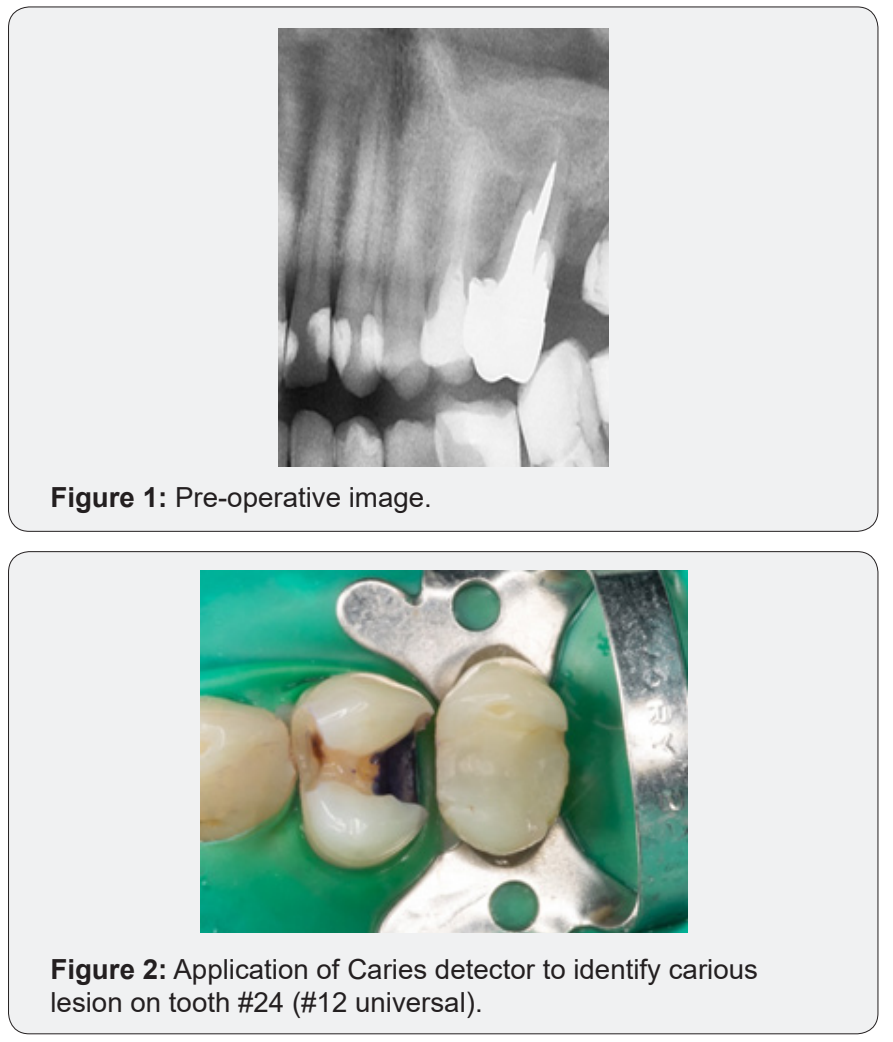

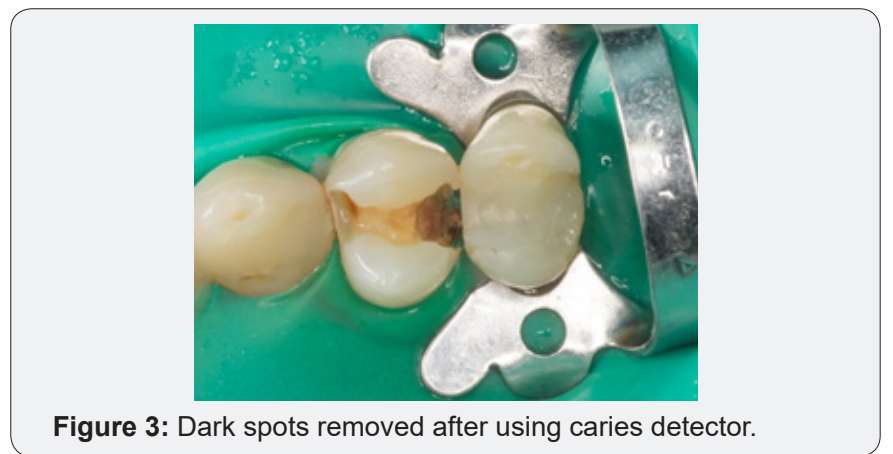

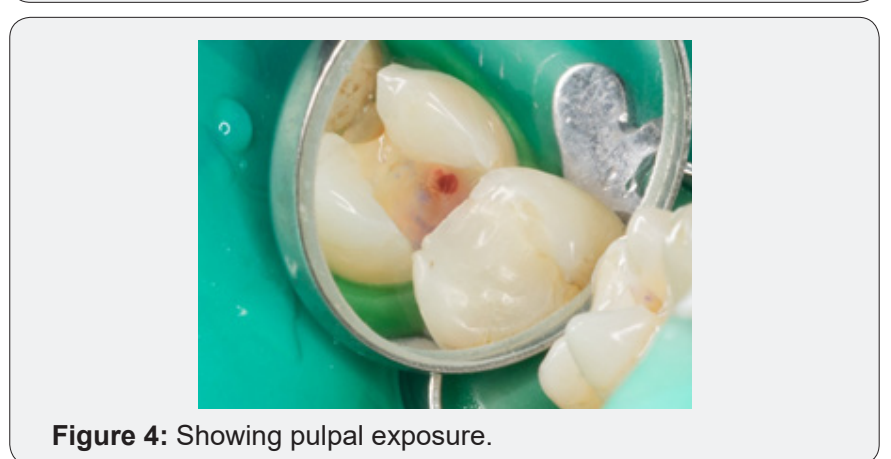

Figure 4: Showing pulpal exposure

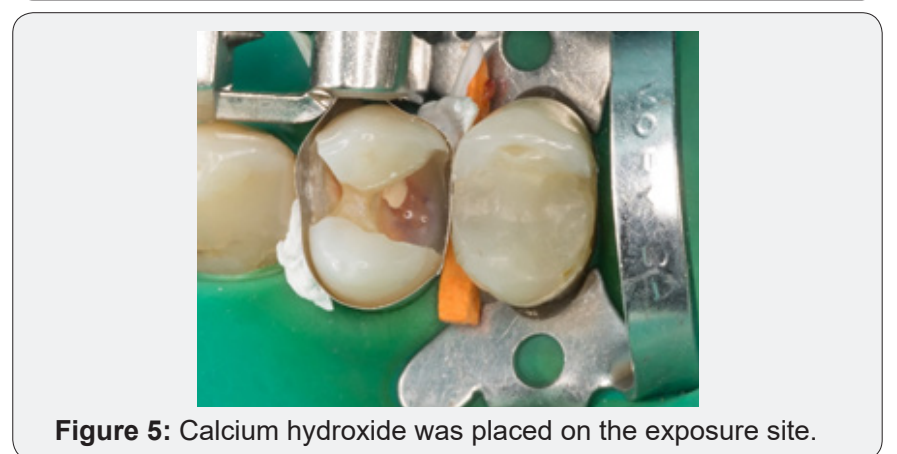

Figure 5: Calcium hydroxide was placed on the exposure site.

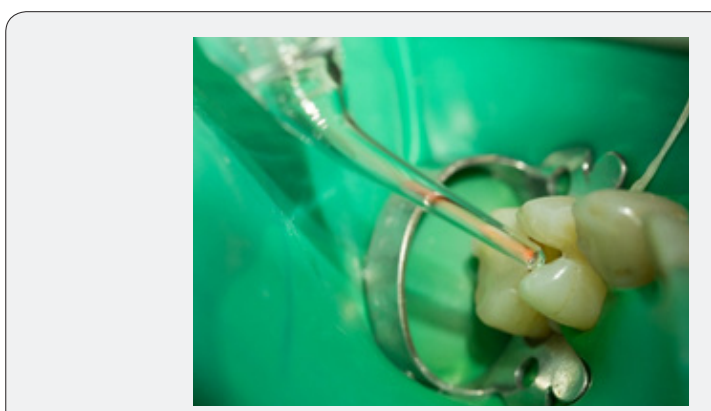

Figure 6: Illustrating the application of gaseous ozone to the cavity floor and dentinal tubules.

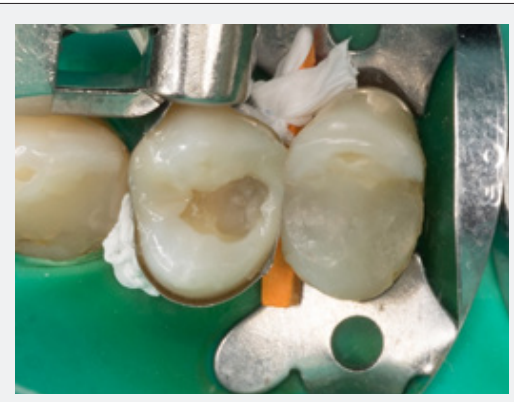

Figure 7: Partially filled tooth with composite. 

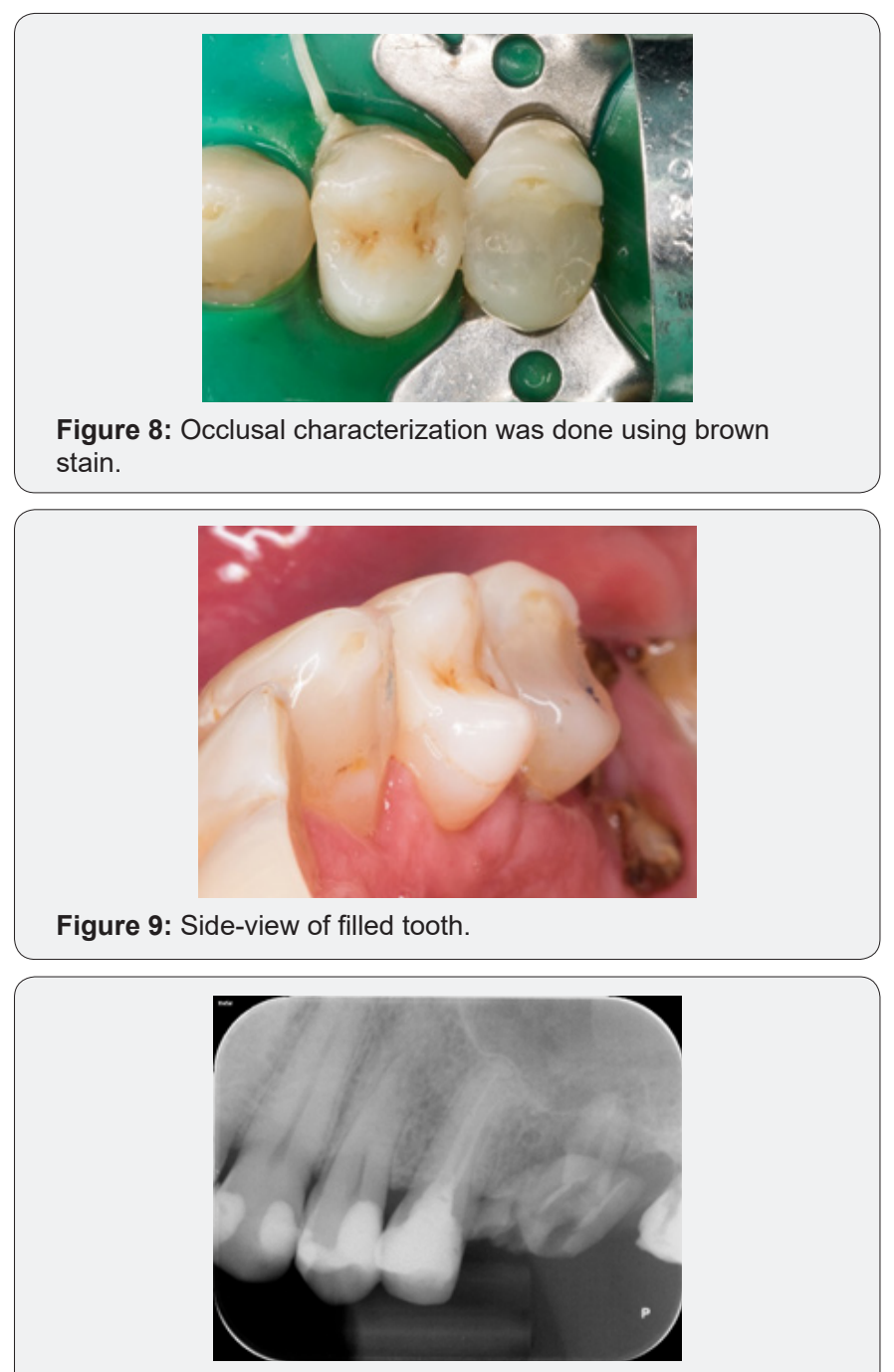

Figure 10: X-Ray taken post-treatment.

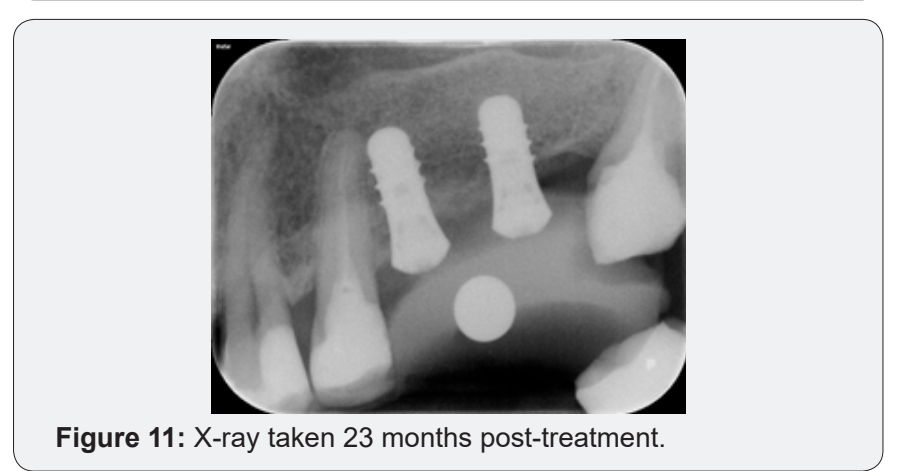

\section{Discussion}

In general, improving dental treatment efficacy is beneficial to both dentist and patients. It avoids many complications leading to more complex dental treatments. In this case there was a minimal pulp exposure while removing the deep caries. The author decided to disinfect the cavity with Ozone before restoring.

It is widely known and accepted among the professional community that complete mechanical removal of caries is not always possible as it would violate pulp. This, in turn, would cause pulpal irritation leading to unnecessary dental treatments and problems such as RCT, post-operative hypersensitivity [8,9].

The reasons for choosing Ozone among all the cavity disinfectants are:

1. Ozone is a very effective alternative in killing bacteria in dentinal tubules

2. Clinicians found Ozone to be more effective in reducing post-operative hypersensitivity compared to Chlorhexidine.

Hence, gaseous ozone was carefully administered to disinfect the dentinal cavity floor. While applying plasma ozone, enough anesthesia was ensured to prevent the patient from feeling the painful electric current. After a 23-month follow-up, this case showed no post-operative complication that could have required an amputative treatment like the RCT. Thus far, the treatment appears to be very effective in achieving intended results. The tooth has remained asymptomatic from the day after the restoration, and it has responded normally to the vitality tests performed during this period.

The use of gaseous ozone did improve the confidence level of dentist and the patient. Its long term effects on its efficacy with this case is still being monitored with assumption that other factors are controlled effectively (such as patient following strict hygiene practices as advised by the dentist). Since there is no evidence in the literature to prove the superior effect of Ozone over chlorhexidine, this case report provides a new path to researchers to explore the comparative effectiveness of Ozone and Chlorhexidine.

\section{Conclusion}

Ozone's bio-compatibility, its effects on micro-organisms and its characteristics including toxicity is well documented in literature review. However, the use of ozone as a well-established approach is not widely in practice in dental offices. This clinical case documented a careful and successful application of gaseous ozone in treating a 41-year-old male patient with pit and fissure carious lesion with mesio-distal extension on tooth \#24 FDA (\#12 ADA).

From the patient's point of view ozone was used as an add-on to traditional methods improving the quality of treatment. From the dentist's point of view, ozone application was easy to use and convenient in disinfecting the cavity floor and dentinal tubules which in turn helps avoiding over-treatments. This outweighs the extra step needed to perform this procedure compared to traditional method of filling the tooth. In addition, ozone as an add-on treatment method offers promising outcomes in improving dentist-patient relationship. Many case reports such as this one will improve adoption of this technique on a wider scale among dental community.

\section{References}

1. CDC (2015) Center for Disease Control. 
2. Dye B, Thornton-Evans G, Li X, Iafolla T (2015) Dental Caries and Tooth Loss in Adults in the United States, 2011-2012. NCHS Data Brief (197): 197.

3. Carvalho JC, Schiffner U (2018) Dental Caries in European Adults and Senior Citizens 1996-2016: ORCA Saturday Afternoon Symposium in Greifswald, Germany - Part II. Caries Res 53(3): 242-252.

4. Gupta S, Deepa D (2016) Applications of ozone therapy in dentistry. Journal of Oral Research and Review 8(2): 86-91.

5. Pattanaik B, Jetwa D, Pattanaik S, Manglekar S, Naitam DN, et al. (2011) Ozone therapy in dentistry: A literature review. Journal of Interdisciplinary Dentistry 1(2): 87-92.
6. Saini R (2011) Ozone therapy in dentistry: A strategic review. Journal of Natural Science Biology and Medicine 2(2):151-153.

7. Ozonytron (2011) MIO International Ozonytron GmbH.

8. de Almeida Neves A, Coutinho E, Cardoso MV, Lambrechts P, Van Meerbeek B (2011) Current concepts and techniques for caries excavation and adhesion to residual dentin. J Adhes Dent 13(1): 7-22.

9. Ratledge D, Kidd E, Beighton D (2001) A clinical and microbiological study of approximal carious lesions. Part 2: efficacy of caries removal following tunnel and class II cavity preparations. Caries Research 35(1): 8-11.

\section{Your next submission with Juniper Publishers} will reach you the below assets

- Quality Editorial service

- Swift Peer Review

- Reprints availability

- E-prints Service

- Manuscript Podcast for convenient understanding

- Global attainment for your research

- Manuscript accessibility in different formats

( Pdf, E-pub, Full Text, Audio)

- Unceasing customer service

Track the below URL for one-step submission https://juniperpublishers.com/online-submission.php 